\title{
POHYB ŽIVOTA A SVĚT \\ O fenomenologii a metafyzice světa u Jana Patočky ${ }^{1}$
}

\section{Karel Novotný}

Obrat k životu se zvláštním zřetelem k tělesnosti znamenal u Jana Patočky určité vykročení jak za horizont husserlovské, tak heideggerovské myšlenkové trajektorie. Patočkova filosofie, od počátku a jako celek, není jen uctivým úsilím o pokračování díla otce zakladatele fenomenologie Edmunda Husserla, očištěným od reliktů tradiční metafyziky, nebo snad jakousi reprízou Heideggerovy kritiky a nahrazení fenomenologie, kosmeticky upravené pro potřeby doby, ale hledáním nových možností myšlení v horizontech, které tito autoři pro filosofii otevřeli, ale právě i za jejich mezemi. V následujícím př́spěvku se chci vrátit k vlastnímu pokusu o nástin celkové charakteristiky Patočkovy fenomenologie filosofie přirozeného světa a podívat se na ni z nového hlediska. ${ }^{2}$ $\mathrm{V}$ posledních patnácti letech se v patočkovském bádání mnohé událo, nepřehlédnutelný je zejména př́nos a vliv nového pojetí zjevování, světa i existence u Jana Patočky, které předložil a ve svém vlastním projektu rozvinul Renaud Barbaras, a to v návaznosti na vybrané texty z 60. let, kde Patočka navrhoval uchopit život, ale i svět sám jako pohyb. Toto zdánlivě jednostranné zaměření na život a pohyb nachází přitom zpětně oporu a i ve světle nedávno zpř́stupněných pramenů z Patočkovy tzv. strahovské pozůstalosti, které Barbaras nemohl znát. ${ }^{3}$

1 Děkuji redakci časopisu Reflexe za pozvání přispět do tohoto čísla věnovaného Milanu Sobotkovi, je to pro mě čest a velmi vítaná př́iležitost popřát svému učiteli k významnému životnímu jubileu.

2 Srv. K. Novotný, Přirozený svět a dějiny. Ke dvěma ohniskům Patočkovy filosofie, in: Hegelovskou stopou. K poctě profesora Milana Sobotky, Praha 2003, str. 155-166.

3 J. Patočka, Nitro a svět. Nepublikované texty ze 40. let, in: týž, Fenomenologické spisy, III/1 (Sebrané spisy Jana Patočky, VIII/I), vyd. I. Chvatík - J. FreiJ. Puc, Praha 2014. Jako první se Patočkovým raným projektem in extenso zabýval F. Karfík, srv. např. jeho studii Patočkova strahovská pozůstalost a jeho odložené opus grande, in: Kritický sborník, 20, 2000/2001, str. 125-160, ale první soustavnější informace o tomto projektu pro zahraniční čtenáře byly publikovány mnohem později. Srv. zejména F. Karfík, Unendlichwerden durch Endlichkeit. Eine Lektüre 


\section{Pohyb života za hranicemi fenomenologie}

Vtělení, od pohybu života živých bytostí neodmyslitelné, lze chápat jako účast živého na dění individuace jako na základním způsobu jevení ve světě. Život, a jeho vtělení, hraje roli na všech úrovních reflexe vztahu člověka ke světu, počínaje klasickým fenomenologickým popisem a interpretací korelace prožitku a přirozeného světa přes interpretaci toho, co reflexivně v prožitku není možné zachytit, protože předmětné korelaci předchází, až např. k tomu hledisku, kde lze i na narození živé bytosti nahlížet jako na vyčlenění těla $\mathrm{v}$ procesu individuace, který je na prožívání nezávislý a děje se ve světě, v dění fysis, kterému všechna těla, stejně jako tělesa či věci patří, z něho vzcházejí a do něho zanikají. Namísto Husserlovy idealistické transcendentální filosofie konstituce světa, kde svět je korelátem konstitutivního života vědomí, navazuje na fenomenologii v užším slova smyslu u Patočky jistá filosofie životního pohybu a živého světa, poukazující k tomu, co jako reflektivně nedostižitelné předpoklady konstituce předchází vědomí a umožňuje mimo jiné korelaci vědomí a jeho předmětů, jevení v běžném intencionálním smyslu. Původní vztah člověka jako živé bytosti ke světu jako celku je tak ve známém konceptu tří pohybů existence a jejich kosmologicko-ontologického rámce charakterizován jako souběh pohybů vitálně-instinktivních a existenciálních, jimž odpovídají takové charaktery světa, které takové pohyby vymezují a umožňují. Snaha brát v potaz svět v širší či hlubší korelaci s životem, jak co do mezí, tak co do možností pohybu života, zřejmě vedla Patočku k tomu, aby i svět sám koncipoval z hlediska pohybu. V některých Patočkových textech z 60. let lze najít určitou oporu pro takové hledisko, jehož samostatné rozvinutí u R. Barbarase ve vztahu k interpretaci Patočkova díla významným způsobem obohacuje nejen jeho recepci v současné filosofii. Pohyb přirozeného světa ve smyslu fysis, to není fyzikální proces, tak jak ho chápou a rekonstruují vědy, to je vyvstávání věcí do světla, ve kterém se ukazují v dějinné perspektivě určitého světa, ale od tohoto ukazování se ve světle světa je ono vyvstávání samo v sobě odlišné, v tom smyslu nedějinné nebo „předdějinné“. Ve vztahu k celkové interpretaci Patočkova díla, k napětí mezi přirozeným světem a dějinami, které v něm lze nacházet, znamená Barbarasovo čtení výzvu podívat se na celek tohoto díla nově, uvážit,

der Philosophie Jan Patočkas, Würzburg 2008, str. 32-43, a edici J. Patočka, Das Innere und die Welt, přel. S. Lehmann, úvod napsala A. C. Santos, in: Studia Phaenomenologica, VII, 2007, str. 26-70. 
jaký prostor Patočka dával dynamice této „předdějinnosti“ fysis a jakou roli př́ípadně v onom základním napětí hrála. Této výzvě a kritickému ohlasu na Barbarasovu práci chci věnovat svůj př́spěvek.

Již v první knize, kterou Barbaras cele věnoval interpretaci Patočkovy filosofie, je formulováno přesvědčení, že ,jeden z hlavních př́nosů Patočkovy fenomenologie spočívá $\mathrm{v}$ tom, co by se dalo označit jako určitá kinetická teorie subjektu, a že jeho filosofii lze v důsledku toho vymezit jako dynamickou fenomenologii“".

Patočkovy texty tak díky Barbarasově čtení otevírají novou perspektivu, jak myslet jednotu přirozeného světa a dějinné existence, a to prostřednictvím zmíněného propojení „dynamické fenomenologie“ a „fenomenologické dynamiky“. Myšlenkové motivy, na které se Barbaras u Patočky soustředí, souvisí přitom do velké míry s vlivem Eugena Finka na myšlení světa, s nímž Patočka konfrontuje svou kritiku subjektivismu Husserlovy fenomenologie a Heideggerovy fundamentální ontologie. Tento vliv představuje ve vztahu k výchozí kontrapozici Husserlova a Heideggerova př́stupu k přirozenému světu a existenci možnou alternativu, která by základní rámec Patočkova myšlení jednoty přirozeného světa a dějinné existence posouvala za hranice fenomenologie směrem, který i Patočka sám naznačuje, když mluví o „,fenomenologii a metafyzice pohybu“. ${ }^{5}$ Otázkou je, kam touto metafyzikou pohybu mírill.

Patočka koncipoval úvahy o původní, přirozené danosti světa ve snaze překonat idealismus Husserlovy fenomenologie již na počátku 40. let. V rukopisech dochovaných v rámci tzv. strahovské pozůstalosti formuloval některé myšlenky, které jsou pak známé z jeho pozdějších prací. Především je v té souvislosti významný obrat $\mathrm{k}$ životu, který dává Patočkově filosofii přirozeného světa nový metafyzický rámec vymykající se nejen klasicky pojaté transcendentální filosofii, ale i jejímu překonávání u Heideggera.

Myšlení tělesnosti, v raném díle ještě nerozvinuté, zaujímá posléze, od konce 50. let, v jeho díle velmi významné místo. Toto myšlení je klíčové v souvislosti s tím, co bývá právem označováno za originální přínos Patočkovy filosofie, pojetí lidské existence jako jednoty tří pohybů, které formálně navazují na Heideggerovu ranou analytiku existence jako

4 Srv. R. Barbaras, Le mouvement de l'existence. Etudes sur la phénoménologie de Jan Patočka, Chatou 2007, str. 65; česky: Pohyb existence. Studie o fenomenologii Jana Patočky, přel. J. Fulka, Červený Kostelec 2016, str. 82.

5 J. Patočka, Phänomenologie und Metaphysik der Bewegung, in: týž, Fenomenologické spisy, III/2 (Sebrané spisy Jana Patočky, VIII/2), vyd. I. Chvatík P. Kouba, Praha 2016, str. 714-731. Český překlad tamt., str. 143-158. 
„bytí na světě“. Oproti tomu však má být svět u Patočky pojat nejen jako existenciál pobytu, jenž je stále ještě korelátem subjektivního rozvrhu smyslu, ale jako žitá půda tělesného pohybu a konání, která hranice každého dějinně relativního rozvrhu překračuje. Hlubší koncept přirozeného světa, o který Patočka usiluje, tak jde ruku v ruce s nutností revidovat samo pojetí lidského „bytí ve světě“. V raném díle se tyto transformace a revize dějí ve jménu a na půdě jisté filosofie života. ${ }^{6}$ A Patočka na to navazuje i ve svém pozdním díle, kde život koncipuje jako pohyb, jemuž odpovídají způsoby, kterými se dává, a zároveň se předmětné danosti vymyká svět sám.

Je pozoruhodné, že již v rukopise „Svět a předmětnost“ $\mathrm{z}$ počátku 40. let, v němž Patočka explicitně ohlašuje pro svou verzi „transcendentální fenomenologie“ nezbytné revize filosofie Husserlovy a Heideggerovy, následuje $\mathrm{v}$ tomto programovém textu závěrečná kapitola, kde je revize požadována právě ve vztahu k otázce „psychofyzického problému“", tedy vztahu tělesnosti a subjektivity. ${ }^{7}$ Ohlašuje se tím v Patočkově myšlení jistý, zatím neprovedený, ale zamýšlený obrat k tělesnosti, na němž bude pracovat intenzivně zejména v 60. letech. Z hlediska těchto pozdějších prací je pozoruhodné, že je v nich možné zahlédnout echo úvah, které rozvíjel v rukopisech z počátku 40. let. Tak si na konci rukopisné prŕípravy přednášky „Fenomenologie a metafyzika pohybu“ $\mathrm{z}$ roku 1968 poznamenal:

„Je sice pravda, že každý pohyb je zároveň jistá seberealizace, jistá modifikace subjektu samého o sobě a modifikace věcí, nebo alespoň

$6 \quad \mathrm{~V}$ tomto duchu charakterizoval rané dílo již F. Karfík, Unendlichwerden durch Endlichkeit. Eine Lektüre der Philosophie Jan Patočkas, str. 32-43. Následně v Reflexi o Patočkově raném projektu proběhla debata, do níž přispěli: J. Puc, $O z ̌ i-$ votě a smrti, in: Reflexe, 36, 2009, str. 25-34, M. Ritter, Odcizené nitro, in: Reflexe, 38, 2010, str. 99-107, J. Frei, Odcizené nitro, nebo zúžené vědomi, in: Reflexe, 39, 2010, str. 105-114, M. Ritter, Nitro a jeho základ, in: Reflexe, 40, 2011, str. 99-104.

7 „Jelikož v našem pojetí transcendentální fenomenologie tím, že na hranici lidského porozumění věcem zahlédnuta čistá příroda, ryzí, do sebe uzavřená nerozlišenost subjektu a objektu, nastala zásadní změna, musí i vztah k různým úsekům filosofické problematiky býti revidován.“ J. Patočka, Fenomenologické spisy, III/1, str. 64. K tomu srv. K. Novotný, Koncept hlubší korelace životní v raných rukopisech Jana Patočky, in: Filosofický časopis, 6, 2017, str. 833-853. Ranému projektu se ve vztahu k tělesnosti věnoval již M. Ritter v článku Nitro a záhada hyletické vrstvy. Poznámky k Patočkovým analýzám těla, zejména ze čtyřicátých let, in: Filosofický časopis, 7, 2011, mimořádné číslo Fenomenologie tělesnosti, str. 81-97. 
všechny tyto dimenze může mít. Ale otázka jednoho, ustavičně se v nás realizujícího pohybu závisí na smyslu tohoto pohybu v celku." ${ }^{8}$

Pozoruhodné je, že se pro jeho osvětlení hodlal přidržovat „pojmů z oblasti života“, aby „pomocí jistých symbolů naznačil smysl a křivku tohoto celkového pohybu“". ${ }^{9}$ Patočka udává směr, kterým by bylo třeba se vydat: „Vycházeje od země jakožto referentu - zakořenění - tíže - opakování - prolomení tíže. Spolubytí, spolupohyb." ${ }^{10}$ Podobným směrem k nárysu filosofie života, za hranice husserlovské fenomenologie i heideggerovské fundamentální ontologie, se Patočka vydal právě již ve válečných rukopisech.

\section{Dvojí koncept světa a těla}

Barbarasův obrat proti transcendentální fenomenologii vede k pozoruhodné formulaci problému původu subjektivity, podle níž

„zrod subjektu se nepřekrývá se zrozením jeho jevů, subjekt se nezapočíná spolu s fenomenalitou, již podmiňuje. Je-li pravda, že přináležitost ke světu je zákonem všech jsoucen, musíme také uznat, že fenomenalizující subjekt sám sebe předchází v nitru světa." ${ }^{\text {"11 }}$

Tento krok zpět před subjektivitu, která je vztahem k jevícím se věcem, je návratem ke světu, v němž jsou věci a bytosti spojeny a zároveň vzájemně odlišeny ještě jiným způsobem než prostřednictvím jevení soustředěného či centrovaného vůči lidskému vědomí jako jeho prožitek. Tímto jiným způsobem má být pohyb vyvstávání jednotlivin, ještě neutrální vůči tomu, jako co tyto jednotliviny budou vnímány v kontextech osvětí živých bytostí. Barbaras svým čtením Patočkova zobecnění aristotelského pojmu pohybu nabízí návrat ke světu jakožto pohybu individuace, který umožňuje utváření osvětí jako významového kontextu založeného na centrovaném způsobu jevení kolem těla, a tím i původní

8 J. Patočka, Phänomenologie und Metaphysik der Bewegung, str. 722. Český překlad tamt., str. 150 .

9 Tamt.

10 Tamt.

11 R. Barbaras, Pohyb existence, str. 108. 
situovanost vtělené subjektivity, ale sám o sobě musí být tento pohyb myšlen vně takového centrování:

„Postulovat principiální přináležitost subjektu ke světu znamená připravovat si půdu pro vysvětlení pohybu, jímž subjekt nabývá své subjektivní bytí, tj. převrací svou přináležitost ke světu do otevřenosti vůči světu. A protože místem, kde se tento pohyb odehrává, je právě tělo, znamená to zároveň promýšlet smysl bytí těla, sestoupit od těla k podmínce jeho vlastní možnosti, k pohybu, díky němuž se rodí jakožto tělo vnímající, zkrátka pochopit, jak se z jistého okrsku světa stává vnímání světa, jak se Körper přeměňuje na Leib. Dodejme, že může-li tělo existovat jen jako situované ve světě, je tomu tak ve vší důslednosti pouze potud, pokud je zde nějaký svět. Situovanost těla, která je vymezuje coby jednotlivé, určité tělo, a která tedy konstituuje jeho tělesnost, je poplatná jeho subjektivaci jakožto podmínce jevení světa, ve kterém je situováno. Subjekt tedy v jednom a témž pohybu nechává vyjevit svět i sebe sama jakožto situovaného ve světě: tělesnost a subjektivita těla, jeho bytí-v-situovanosti a jeho bytí-v-otevřenosti vůči světu, se rodí společně z určité situovanosti v původnějším smyslu." ${ }^{\prime 2}$

Zmíněná původní situovanost na základě dění světa samého, které umožňuje a předchází jevení v korelaci jevícího se a subjektu, je alternativou k Husserlovu i Heideggerovu pojetí původu přirozeného světa, inspirovanou Merleau-Pontyho reverzibilitou mezi smyslově pocit'ovatelným a pocit'ováním, kterou Barbaras reformuje prostřednictvím zobecněného pojmu pohybu tak, aby vposled pohyb živého do světa byl prodloužením původnějšího pohybu smyslového světa samého. Toto vykročení z reverzibility vzájemného pohybu prostupování ve prospěch ontologického monismu světa jako pohybu individualizace je třeba vzít v potaz a konfrontovat s Patočkovými texty. Barbaras tuto alternativu, toto čtení Patočky nastiňuje ve své knize těmito slovy:

„Poněvadž subjekt se jeví jako odvozený a poněvadž fenomenalita světa se tím pádem jeví jako něco, co povstává z pohybu fenomenalizace, musíme připustit, že existuje bytostný smysl světa, který není totožný s jeho vyjevujícím se bytím, nýbrž představuje naopak půdu a podmínku možnosti jeho vlastní fenomenality. Na Patočkovo myšlení v tomto ohledu zapůsobil rozhodujícím vlivem Eugen Fink.

12 Tamt., str. $108 \mathrm{n}$. 
... Je to právě svět, jak píše Patočka, ,co zjevy jako takové kloubí, je zároveň tím, co jim dává určitost, vymezení i omezení, vnitřní i vnější výstavbu; jsa sám v základu svého kloubení temný, vynáší vše do světla zjevování. Skladebný zákon světa tak vládne jakožto něco skrytého, co není ani něčím jednotlivým, ani sumou či totalitou jednotlivostí, nýbrž tím, z čeho zjevy a vše, co je jasné, i tato jasnost sama, pramení' "“13

Jak naznačuje závěr tohoto textu, svět, jak jej podle Barbarase Patočka v návaznosti na Finka chápe, je ,zároveň zdrojem jsoucen i zdrojem toho, co je dovádí ke zjevnosti, je zdrojem toho, co se zjevuje, i události jevení". ${ }^{14}$ Tak jevení jsoucen nejen není myslitelné pouze jako dílo subjektu, „zakládání smyslu“ v intencionálním prožitku, ale je především, ba výlučně dílem světa, a to v tom smyslu, že ještě než se stanou jsoucnem pro nějaké vědomí, dospívají věci právě ve světě a skrze něj $\mathrm{k}$ individuaci, která teprve ono jevení pro vědomí v určitém natolik základním ohledu umožňuje, že klasický transcendentální subjekt jako původce jevení zcela nahrazuje. Tato myšlenka vede Barbarase k závěru: „Naše schopnost fenomenalizace, tj. naše subjektivita, přebírá a dovršuje proces, který probíhá ve světě a jehož je svět takříkajíc subjektem." ${ }^{15}$ Finkovo rozlišení dvou způsobů jevení Barbaras jednoznačně vkládá do základů Patočkovy fenomenologické filosofie, která se mu proto zdá být fenomenologickou kosmologií (avant la lettre, vzhledem k jeho vlastní koncepci).

Jak už bylo řečeno, Patočkovu originalitu je podle Barbarase třeba jednoznačně spatřovat $\mathrm{v}$ jeho zobecnění pojmu pohybu. ${ }^{16}$ Naopak

13 Tamt., str. 109 n. Citát zahrnutý v této pasáži je z článku Jana Patočky Celek světa a svět člověka, in: Fenomenologické spisy (Sebrané spisy Jana Patočky, VII), vyd. P. Kouba - O. Švec, II, Praha 2010, str. 438.

14 R. Barbaras, Pohyb existence, str. 114.

15 Tamt.

16 Srv. k tomu Patočkova slova o knize Aristotelés, jeho předchůdci a dédicové (Praha 1964): „Základní myšlenka mých historických úvah je následující: Dění a pohyb, v nichž mají původ všechny naše zkušenosti, jsou samy nemožné bez hlubšího a základnějšího dění, které již není pohybem ve zkušenosti a ve světě, nýbrž děním a pohybem světa jako takového, děním ontologickým... Pokouším se ukázat, že i u Aristotela má pohyb stále ještě tuto hlubší funkci zdroje bytí (a pravdy) věcí vedle své funkce a skrze svou funkci nitrokosmické, empirické události.“ Dopis R. Campbellovi z 20. března 1964, citovaný v článku F. Karfíka Odyssea zkonečnělého absolutna, in: Myšlení Jana Patočky očima dně̌ní fenomenologie, Praha 2009, str. 48 n. 
Barbarasův vklad vidíme $\mathrm{v}$ tom, že subjektivní pohyb těla pokládá za participaci na pohybu, který je způsobem bytí samotného světa a těles v něm. Ve „Fenomenologii a metafyzice pohybu“, na úrovni fenomenologické analýzy korelace subjektivního pohybu těla a světa, však pro Patočku oba členy korelace nepochybně zůstávají stejně původní. To ještě samo o sobě nemusí nutně znamenat dostatečný argument proti Barbarasově tezi, protože ta se týká metafyzické interpretace jejich „kloubení“, Fügung, která, jak Patočka sám v tomto textu píše, vyžaduje obrat k ,pojmům z oblasti života““ ${ }^{17}$

\section{Problém dualismu}

Překonání dualismu existence a světa má poskytnout takové pojetí pohybu, které by vystihovalo jak individuaci jednotlivin $\mathrm{v}$ rámci předchůdného celku světa „,bez subjektu“, tak subjektivní existenci jako odhalující a explorující pohyb těla, který - dodejme s odkazem na Patočkovy texty - se k jednotlivinám a jejich prostředí vztahuje realizací možností, které mu nabízejí. ${ }^{18} \mathrm{Je}$ zřejmé, že pohyb individuace a realizace tu ovšem neznamenají tentýž pohyb, naopak, právě Barbaras klade důraz na to, že jeden je z jistého hlediska primární vůči druhému, nebot' věci tu zřejmě musí nejprve být, aby se mohly stát prostředkem realizace možností pro pohyb živé bytosti, problematický se ale zdá závěr, který zde Barbaras razí, ${ }^{19}$ a to, že subjektivita je otevřena světem:

„Jak jsme již řekli, fenomenalizující otevřenost je sekundární v tom ohledu, že předpokládá, aby subjekt této otevřenosti, stejně jako ostatní jsoucna, byl otevřen světem: tato nutnost, spočívající v propojení subjektu a ostatních jsoucen, je zároveň zdrojem toho, co je jasné, i jasnosti samé (subjektu). ${ }^{(20}$

17 Srv. výše pozn. 8, 9, 10. K této diskusi srv. K. Novotný, Subjektivní pohyb těla a svět. Poznámky o fenomenologii a metafyzice tělesnosti v reflexích Jana Patočky, in: Filosofický časopis, 7, 2001, mimořádné číslo o Filosofii tělesnosti, 2011, str. 47-68.

18 Srv. J. Patočka, Tělo, možnosti, svět, pole zjevování, in: týž, Fenomenologické spisy, III/2, str. 310.

19 Tohoto závěru se sice nevzdává tak docela ani v současných, vlastních knihách, kde se s Patočkou explicitně rozchází, ale pozoruhodný je obrat k metafyzice události subjektivity, která je, počínaje knihou La vie lacunaire, Paris 2011, jeho způsobem, jak se vyrovnat s neodvoditelností momentu subjektivity z dění světa.

20 R. Barbaras, Pohyb existence, str. 114. 
Problematické se zdá to, že by jasnost sama měla mít svůj jediný původ $\mathrm{v}$ tom, co je z podstatných důvodů samo v sobě třeba chápat spíše jako temný, v sobě uzavřený „,základ“, jak se o něm vyjadřuje Fink, jehož vliv tu explicitně Barbarasovo čtení Patočky vyzdvihuje. Jeho interpretace se opírá především o jedno místo z rukopisné pozůstalosti, o fragment, který souzní nepochybně se „základní myšlenkou“ Patočkových „historických úvah" o Aristotelovi, ale je formulován v rukopisném konceptu k článku věnovaném Finkově filosofii, tedy přece jen $v$ jiném kontextu:

„Zjevování jako východisko z temného základu; že je tu pohyb zjevování, prapohyb, možno vyčíst per analogiam z druhotného zjevování, totiž zjevování zjevu, který předpokládá tvoření center, centrality: pohyb transcendence vytváří tu ,vlastní svět‘, osvětí... Právě tak musí existovat cosi jako pohyb, kterým srdce světa vytváří svůj nahodilý obsah a jehož sedimentem je prostoročasokvalita v celku. ${ }^{\text {" }}{ }^{21}$

Tento pohyb, prapohyb, je svět, tak jak ho koncipuje Barbaras. Novost a radikalita jeho koncepce spočívá nejen $v$ důrazu na přináležitost subjektu ke světu, na světskou absorpci mimosvětské pozice transcendentální subjektivity, která místo aby konstituovala svět, je spíše ze stejné látky jako on a jím utvářena, ale také v pojetí tohoto utváření jako ontologického či „ontogenetického“ pohybu, kdy Barbaras překračuje Merleau-Pontyho myšlenku vzájemného prolínání tělesnosti světa a živých bytostí směrem k „radikálnímu ontologickému monismu“ světa, k překonání tradiční duality subjektu a světa kosmologickým zobecněním pohybu, který je vposled pohybem světa samého a který je sám svým jediným zdrojem. Subjektivita má být podle Barbarase otevřena světem, ale je-li ten pohybem původní individualizace jsoucen, který se rovná produkci jejich - ještě anonymních, ,a-subjektivních“ - jevů, mohou z tohoto pohybu vyplynout pouze jevy těla ve smyslu Körper. Jeho proměna $\mathrm{v}$ Leib nepatří $\mathrm{k}$ entelechia takového pohybu, ledaže by byl pohybem teleologicky $\mathrm{k}$ takovému obratu předurčeným, což si Barbaras kategoricky zakazuje. Jeho nárys kosmologické metafyziky sice veškeré bytí a jevení zakládá na pohybu světa pojatého jako fysis a chápe tento pohyb jako „původní život“, „Život“" světa samého - dá se říci, že tím podobně jako Heidegger a Fink vrací do hry presókratovskou kosmologii a radikalizuje motivy, které bychom mohli najít i v záhybech Patočkova

21 J. Patočka, K článku ,Weltganzes und Menschenwelt“, in: týž, Fenomenologické spisy, III/2, str. 501. Citováno u R. Barbarase, Pohyb existence, str. 115. 
myšlení -, ale moment subjektivity živého těla $\mathrm{z}$ tohoto pohybu vyvodit nelze. Na tento problém naráží i Barbarasova interpretace Patočkova myšlení, která vyúst'uje v kritiku určitého reziduálního dualismu dvou prvních pohybů života a tzv. třetího pohybu ducha.

Revize, kterou je třeba vzít $\mathrm{v}$ úvahu, by směřovala $\mathrm{k}$ vychýlení takové ještě klasické dualistické balance pohybu okolo dvou ohnisek ve prospěch jednoho ohniska všech pohybů existence v tělesném životě. Napětí „ducha“" se tím ovšem proto ještě nestává pouhou iluzí, vždyt' v něm jak známo naopak pro Patočku tkví pravá bytnost člověka, jeho transcendující otevřenost. Na tom se nic nemění, vazba této transcendence na život je ale užší, než jak si to představuje metafyzický dualismus, a na to jednoznačně poukazuje i Barbaras, mj. pojetím podstaty subjektivity jako touhy. Ducha či lidskou svobodu nelze klást do umělého protikladu k životu, ale také je nelze jednoduše z nějakého obecného pojmu života, např. jako pohybu (světa), odvodit, aniž bychom je tomuto pohybu podložili jako jeho skrytý telos.

\section{4. „Předdějinnost“ přirozeného světa}

Jan Patočka podal svou filosofickou pozici v jediné knize, kterou dokončil a sám i publikoval, byt' v samizdatu, nazvané Kacírské eseje o filosofii dějin. O významu knihy svědčí i fakt, že pracoval rovněž na jejím vydání v zahraničí, pro které ovšem stihl přeložit do němčiny jen její první části. Náš autor nepochybně směřoval k určité alternativě ke klasikům fenomenologie, o tom svědčí celé jeho dílo, tím spíše by měly být její obrysy patrné právě i v této, vlastně jediné vlastní systematické Patočkově knize. Na její patřičně důkladnou interpretaci na tomto místě nemůžeme pomýšlet, ale pokusme se alespoň $v$ jejích úvahách o ,,př́eddějinném přirozeném světě“", tedy v prvním eseji, najít odkaz k životu a hlubší korelaci života a světa. Tento motiv ,života“ před dějinami a „předdějinného světa“ má být tedy na závěr odlišen od husserlovské i heideggerovské koncepce dějinnosti světa a existence $v$ něm.

A to je přesně strategie prvního kaciřského eseje. Ten totiž má dvě části. Nejprve Patočka ukazuje historický původ otázky po přirozeném světě a její uchopení u Husserla a Heideggera. Závěrem této části je konstatování, že neexistuje žádný přirozený svět, který by nebyl dějinný. Na to následuje druhá část, kde Patočka naproti tomu přichází s obratem $\mathrm{k}$,předdějinnému“ životu a jeho světu. Tak je závěr první části věnovaný ,jedinému řešení, které nejvíce vyhovuje všem požadavkům a obtížím 
problému přirozeného světa““,22 tedy že lidský život je vlastně transcendující „otevřenost“ a „nic jiného“. Heideggerovo pojetí světskosti pobytu jako života transcendujícího do „otevřenosti“ se tak sice Patočkovi „zdá být dosud nejnosnější základ“" pro řešení problému, zároveň mu ale něco podstatného chybí, a to právě pochopení toho, z čeho život do osvětleného „světa“, otevřeného porozuměním bytí, vchází a do čeho se vrací. ${ }^{23} \mathrm{~K}$ tomu se nyní obrací celá druhá část prvního kacířského eseje. Jak je tento obrat zamýšlen? Ve druhé, a poslední verzi prvního eseje Patočka svou strategii shrnuje slovy: „Pokusili jsme se o jisté podání lidského ,světa“ $v$ té etapě, kde se nacházíme teprve na prahu dějinného procesu: o jisté podání předdějinné půdy, na níž se teprve zdvíhá stavba dějin ve vlastním smyslu. “24

Toto podání navazuje na referát o Heideggerovi s tím, že ten se v souvislosti se svým zaměřením na problém bytí věnoval jen jednomu ze základních pohybů lidského života, který pojal jako vztah k budoucnosti pohybující se mezi póly autenticity, „vlastního“, a odcizenosti.

„Co však této pozoruhodné polaritě dějinného časování předchází, je život $\mathrm{s}$ úplně jiným temporálním charakterem... Toto prožívání bytostné vázanosti na minulost, $v$ němž budoucnost a př́tomnost vypadají jen jako závislé obměny, je časovost předdějinného s jeho původní závislostí na božském ,již‘, na prasvětě a pračase, s jejich bytostnou spoutaností se zemí, v souvislosti s tím však také s bytostnou polaritou svátečního a každodenního.“25

Ve vztahu k dějinnému prožitku času a světa, k tomu, co i Patočka pokládá za nejvýznamnější, tzv. „třetí“ pohyb existence, je třeba při řešení otázky přirozeného světa vzít vážně ještě jiné pohyby, které se dějí v korelaci se světem,

„,V němž je zdůrazněn charakter onoho ,již‘, minulosti, která je zcela ne-vlastní (un-eigentlich), kterou my opakovat nemůžeme, nýbrž

22 J. Patočka, Kacířské eseje k filosofii dějin, in: týž, Péče o duši, III (Sebrané spisy Jana Patočky, III), vyd. I. Chvatík - P. Kouba, Praha 2002, str. 19, pozn. a (523). Překlady mírně upravuji, v závorkách odkazuji na německý originál otištěný v témže svazku.

23 Tamt., str. 27, pozn. a (30).

24 Tamt., str. 40, pozn. a (547).

25 Tamt., str. 27, pozn. a (531). 
v níž člověk existuje tak, že se cítí odkázán na přízeň, na to, co je uchvacující a přemocné, na to, co unáší, na vytržení, únos, raptus“ ${ }^{\text {“ }}{ }^{26}$

Pozoruhodná je myšlenka „nadbytku“, „přemíry plnosti“", která z tohoto předdějinného světa přichází. Její prožitek ,je vázán na tělesnost“. Přemíra plnosti, „překonávající každé očekávání“, je

„vázána na všechno to, co s sebou přináší naše tělesnost, na níž lpí rovněž zásadní akcent na ono ,již , ve své spjatosti s druhými, s dary země a pozemského života, $\mathrm{s}$ tím, co v našem tělesném prožívání má povahu látky, co propojuje a činí splývavým, sjednocuje, není uzavřené a zcela in-dividuované“. 27

Kdybychom chtěli prokázat návaznost rané Patočkovy revize Husserlovy a Heideggerovy filosofie obratem k životu a tělesnosti, který je poprvé soustavně rozvržen $\mathrm{v}$ rukopisech $\mathrm{z}$ raných 40 . let, zahrnujících ostatně rozsáhlé rešerše o mytickém vědomí, bylo by právě citované místo jedním z hlavních opěrných bodů. Není zde třeba tuto návaznost detailně rekonstruovat, aby bylo zřejmé, že Patočkovo sledování toho, co je třeba pod povrchem Heideggerovy konstrukce dějinnosti v polaritě „vlastního“ a „odcizeného“ porozumění bytí vzít v potaz, je život, který ve své tělesnosti, ve vázanosti na sebe, „odcizuje ještě hlubším způsobem“ než „sebezapomínání v nivelujícím“, každodenním, veřejném, neautentickém „pojetí bytí jako reality“. Důležité je však právě to, že tímto „odcizováním“ živá bytost do světa původně vrůstá, a ne „upadá“, jak zní Heideggerovo diktum, proti němuž se zde Patočka vymezuje, stejně jako již ve svých raných textech, kde tuto dimenzi nazývá „,předkaždodennost “ ${ }^{28} \mathrm{~V}$ rozpracované podobě tuto dimenzi známe $\mathrm{z}$ konceptu prvního a druhého pohybu života. O nich se Patočka v prvním kacířském eseji vyjadřuje nejprve obecně, jako o pohybech, které nemají za cíl otevřenost, tedy transcendenci. A když pak ve druhé části eseje zavede pojem přirozeného světa jako světa „předdějinného“, píše o zakořenění života ve světě a o práci a výrobě, což jsou způsoby původní hlubší korelace života a přirozeného světa, jehož ,předdějinnost“ je východiskem pro

26 Tamt., str. 28, pozn. a (532).

27 Tamt.

28 Srv. např. stejnojmennou kapitolu rukopisu o „,fenomenologické teorii subjektivity“ z počátku 40. let, in: J. Patočka, Fenomenologické spisy, III/1, str. 213-221. 
vlastní nárys filosofie dějin. Patočka v této druhé části prvního kacířského eseje věnuje prostor několika interpretacím předdějinného světa jako půdy pro vlastní dynamiku evropského dějinného způsobu existence, která je pak hlavním tématem jeho knihy o „filosofii dějin“.

Naším záměrem tu nemůže být znovu a nově tuto filosofii dějin prezentovat. V této krátké referenci ke Kacířským esejům se spokojujeme s poukazem na to, že Patočkova filosofie dějin vyrůstá z alternativního pojetí přirozeného světa, které nás tu především zajímá a k jehož osvětlení zároveň z „druhé strany“ filosoficko-dějinná perspektiva přispívá. Husserlovo hledání invariantu hlubší korelace životní, „přirozený svět jako filosofický problém“, který Patočku zaujal již na počátku jeho myslitelské cesty a dal jí možná rozhodující impuls, tu nachází svůj nový výraz, který ostatně za mnohé vděčí E. Finkovi. ${ }^{29}$

\section{Závěry}

Genezi pohybu života, tedy subjektivní tělesnosti Leib jako způsobu zniternění přináležitosti světu, která se děje primárně skrze jsoucí tělo, Körper, R. Barbaras zprvu vykládal jako „otevřenost světem“, tedy jako událost světa samého: svět má být vposled tím pohybem, kterým nastává jevení a s ním subjektivita. Ve snaze vysvětlit původ jevení, kterou Barbaras intenzivně vyvíjel ve svých interpretacích tohoto ústředního bodu a kterou domýšlí do důsledků ve své vlastní filosofické koncepci, je tato tendence stále zřetelněji vyjadřována a konfrontována se svým vnitřním limitem - dodal bych: z titulu určité kritické výhrady, která je nasnadě, totiž že vznik subjektivity nelze fenomenologicky objasnit jako dění či pohyb světa samého, pokud ten koncipujeme jako na subjektu nezávislý děj (a ne spolu s pozdním Merleau-Pontym jako chiasmus, či jen jako rozvrh světa či horizont, nebo „světskost“ jako existenciál pobytu). Pro transcendentální fenomenologii, jak ji Patočka podává v různých verzích od počátku 40. až do poloviny 70. let, je nepochybně subjektivita (nikoli subjekt jako substance) původním faktem či událostí na jakýkoli empirický světský pohyb či světské dění neredukovatelnou, faktem či událostí

29 Z hledisek otevřených Finkovou filosofií přispěl k novým pohledům na $\mathrm{Pa}-$ točkovu filosofii významným způsobem Hans Rainer Sepp, srv. Schriftenverzeichnis, in: C. Nielsen - K. Novotný - Th. Nenon (vyd.), Kontexte des Leiblichen, Nordhausen 2016, str. 551-569. Soustavné srovnání nabízí článek Ivana Blechy Pojem světa u Finka a Patočky, in: V. Leško - R. Stojka aj., Patočka a filozofia 20. storočia, Košice 2015, str. 151-168. 
vymykající se nejen pokusům o „naturalizaci“vědomí, ale i pokusům o redukci subjektivity na produkt výkladu, symbolického ustavení. Ovšem, svět, o kterém uvažuje Barbaras, není ontickým, ale ontologickým pohybem, děním, které jevení světa i jeho adresáta teprve plodí tím, že zakládá možnost jejich korelace. $\mathrm{K}$ tomu směřuje Barbarasovo úsilí o rozplétání Merleau-Pontyho myšlenky chiasmu.

Na tomto postupu lze rozlišit dvojí směr metafyzického vykročení za fenomenologickou deskripci. Na jedné straně uznání určité reverzibility či vzájemné odkázanosti v tom smyslu, že pojetí světa jako pohybu anonymní manifestace předpokládá dospívání tohoto pohybu do jevení pro vtělenou subjektivitu života, z níž fenomenologická analýza korelace vychází, představuje výzvu myslet to, co tuto korelaci umožňuje. U Barbarase je to krok za fenomenologii ke kosmologické filosofii pohybu či „radikálnímu ontologickému monismu“. ${ }^{30}$ Fakt, že si konečný život pozemských tvorů nedává své možnosti sám ze sebe, ale je odkázaný na jejich vyvstávání ze světa, ovšem neznamená, že se takové možnosti jeví nezávisle na něm. Ve vztahu ke kosmologické nebo naopak transcendentální předchůdnosti jednoho vůči druhému proto filosofové, jako např. Jean-Luc Marion, mluví o jevení jako takovém jako o události. Událost jevení či dávání, pokud jde o Mariona, by pak byla z jistého hlediska tím prvním, co umožňuje všechny modality vztahu ke světu, počínaje nejbazálnější úrovní pocit'ujícího a perceptivního života jako pohybu do světa. K tomu se ale takříkajíc již vždy musel poskytnout svět, který pro tento pohyb dává prostor, poskytuje mu čas, jak o tom čteme u Finka, a který sám může být pojat jako pohyb, zahrnující do sebe už vždycky všechny životní pohyby. ${ }^{31}$

Na straně těchto životních pohybů je ale ještě jiný předpoklad, který ani touto událostí jevení jako takového ani pohybem světa nelze osvětlit, a to je ona záhada, kterak „se Körper přeměňuje na Leib“.32 Je to

30 Srv. R. Barbaras, La métaphysique du sentiment, Paris 2016, str. 198 aj.

31 E. Fink, Welt und Geschichte, in: týž, Nähe und Distanz, Freiburg - München 1976, str. 178: „Dimenze světa jsou do sebe navzájem proniknuté v jednom neustávajícím pohybu, pro který nemáme žádná ontická jména. Je to veliký světa-pohyb jevení, který konečné věci vystavuje do otevřena a po chvíli trvání, kterou jim uděluje, je bere zpět do tvarů prostého základu.“ Dimenzemi světa se tu míní „jasná krajina rozlišení a temná, nepopsatelná krajina vše-jednoty“, k níž se blížíme láskou a do níž se vracíme smrtí, „které tvoří takř́íkajíc dějin prostou půdu dějin (geschichtsloser Boden der Geschichte)“.

32 Srv. k záhadě „oduševněni““ těla E. Husserl, Grenzprobleme der Phänomenologie, Dordrecht 2014, str. 141, (Husserliana, XLII): „Tohle je přece ona záhada 
proměna těla jako věci v živé tělo, která je sice pro jevení, pro pohyb živých bytostí do světa nezbytnou podmínkou, ale těžko ji můžeme chtít osvětlit z události vyvstávání věcí, které se mohou stát možnostmi pro tento pohyb života. Jako pocit'ovatelnost smyslového světa v jistém ohledu předchází jeho smyslovému pocit’ování, tak i citlivost v jiném ohledu předchází cítění, ale chiasmus obou - jejich vzájemné proplétání -, uskutečňující se i díky události jevení, poukazuje ze sebe ven, vně monistické imanence či ontologické spřízněnosti života a světa, $\mathrm{k}$ tomu, co je překážkou jejich vzájemného splynutí.

A to je na jedné straně svět $v$ tom, co je $v$ něm subjektivitě a jevení podstatně cizí, co nevychází nikdy na světlo a zůstává v sobě, a na druhé straně to, co se tohoto cizího v životě přesto dotýká: tělo, které se cítí, je podmínkou tohoto doteku, v němž se ale ještě sobě samému nejeví a jemuž se ještě nejeví ani nic mimo něj, ale které se možná právě až tímto dotykem s nepoddajným a cizím stává citlivým, citlivým pro jiné i pro sebe. Tento dotyk se děje pod událostí jevení, nevchází do ní, je vně fenomenality, onoho osvětleného pole jevení, které má podobu toho či onoho historického světa. Barbaras se k tomuto dotyku přibližuje ve svých posledních knihách v rámci metafyziky afektivity či sentimentu, který je kontaktem konečného života, jehož podstatou je touha, s Životem světa, který je této touze vším. ${ }^{33}$ Možná že i u Patočky je to vposled touha po světě, po souznění s ním, kterou naplňuje první pohyb života, ale podmínkou lidské realizace tohoto pohybu je láska druhého člověka, bez které i svět zůstane cizím, mrazivým prostředím, a touha po něm se nemůže roznítit. Možná by se ale nemohla roznítit ani tehdy,

života. Vlastní záhada nespočívá ve vzniku organických bytostí jakožto fyzikálních věcí, a záhadné není ani to, že se objektivně pojaté [fyzické události] utvářejí jako organické události např́íklad tak, že vytvářejí specifické procesy plození, vyživování, látkové výměny atd. At' už si vystačíme s obvyklou fyzikou nebo ne: to, co jako jediné principiálně překračuje hranice fyziky, je oduševnění (Beseelung).“

33 Je to podle Barbarase svět, po kterém i v nejintimnějším vztahu k druhému člověku vlastně toužíme. Srv. R Barbaras, Le désir et le monde, Paris 2016, str. 190 nn. V tomto bodě se vzdaluje Patočkovi, pro něhož pohyb přimknutí ke světu, tzv. první pohyb života, jako touha souznít se světem, je umožněn přijetím ze strany druhého člověka. Myšlenku dotyku se světem jako cizím, nepoddajným elementem pokládám za určité manko Barbarasova vlastního filosofického projektu, ale to nesouvisí s jeho interpretací Patočky, u něhož také není centrálním motivem, i když u něj hraje důležitou roli právě v pojetí prvního pohybu, jímž je cizost světa překonávána, ale nikdy zrušena. K Barbarasově projektu srv. z tohoto hlediska K. Novotný, Die Welt und das Ereignis des Erscheinens. Bemerkungen zu einem zeitgenössischen kosmologischen Ansatz, in: C. Nielsen - H. R. Sepp (vyd.), Eugen Fink. Erde - Wohnen - Natur, Würzburg 2018 (v tisku). 
kdyby svět zároveň neměl tuto dimenzi cizího a neprostupného, čím svět nejen dává místo a poskytuje čas, ale klade také odpor, zůstává v sobě, odpírá se světlu, které si v chiasmatu se svým prostředím život kolem sebe, do svého osvětí, vrhá. A přes tento odpor a díky němu je svět tím, co jako země hlubší korelaci životních pohybů a jejich prostředí zároveň nese. I tyto momenty, které promýšlel Fink, lze zahlédnout v Patočkově filosofii. ${ }^{34}$

Barbarasovo čtení Patočky, třebaže v tomto posledním bodě nejde stejným směrem nebo přinejmenším ne tak daleko v akcentování temné, nedostupné, do sebe uzavřené stránky světa jako Fink, nám pro hlubší korelaci života a světa může otevírat oči tím, jak jednoznačný důraz klade na to, co u Patočky spadá pod koncept předdějinného světa. V tomto konceptu můžeme mimo jiné vidět Patočkovu alternativu k myšlení přirozeného pojmu světa neoddělitelného u Husserla a Heideggera od dějinnosti vědomí, pobytu či porozumění bytí.

Přiblížit tento rozměr přirozeného pojmu světa bylo cílem tohoto článku, jsem si ovšem vědom toho, že jasnější závěry o této alternativě zůstávám čtenáři dlužen. ${ }^{35}$

\section{ZUSAMMENFASSUNG}

Eine neue Interpretation der natürlichen Welt bei J. Patočka, erschlossen durch R. Barbaras, stützt sich - gegenüber der Auffassung seiner Philosophie als einer Synthese der Bewusstseins- oder Reflexionsphilosophie E. Husserls und des seinsgeschichtlichen Denken M. Heideggers - auf Patočkas Hinweise auf einen tieferen Standpunkt, auf ein Leben im Sinne der Physis oder Natur, die ein gewisses Fundament für die Dynamik der Weltbildung darstellt. Jedoch entzieht sich dieses Fundament zugleich dieser Dynamik, was bei Barbaras vielleicht nicht genug berücksichtigt

34 Za tuto myšlenku odporu tělesně pocitovaného vnějšku, pod prahem fenomenality, která u Patočky není nikterak ústřední, vděčím především H. R. Seppovi, ale nacházím ji již u E. Lévinase. Srv. k tomu podrobněji ve druhé a třetí části knížky K. Novotný, Relevance subjektivity, Červený Kostelec 2016.

35 Článek je výstupem grantového projektu „Život a prostř̌edí. Fenomenologické vztahy mezi subjektivitou a přirozeným světem“ (GAČR 15-10832S). Recenzentovi mého článku mnohokrát upř́ímně děkuji za připomínky a podněty $\mathrm{k}$ přepracování. Při práci na těchto tématech, v rámci chystané monografie o vztahu života a světa ve fenomenologické filosofii, je budu moci vzít v potaz ve větší míře, než se dalo stihnout v poslední autorské úpravě tohoto př́íspěvku. 
wird. Diese Hinweise münden in die Auffassung der natürlichen Welt als einer „,vor-geschichtlichen“ Welt, aber knüpfen auf Begriffe einer „Voralltäglichkeit" und „reiner Natur“" aus Patočkas frühen Manuskripten vom Anfang der 40er Jahren an.

SUMMARY

The new interpretation of the concept of the natural world in J. Patočka, introduced by R. Barbaras, as opposed to the interpretation of his philosophy as the synthesis of the philosophy of consciousness or reflective philosophy in E. Husserl, and of the thinking of being in its historicity in M. Heidegger, is grounded in Patočka's references to a deeper starting point - life in the sense of phusis or nature - which represents a basis of a world-formation dynamics and which, at the same time, which Barbaras perhaps may not have considered enough, eludes this dynamics itself. These references result in the concept of the natural world as the "pre-historical" world, in the first Heretical Essay on the Philosophy of History, and follow from the concepts of "pre-everydayness" and "pure nature" in Patočka's manuscripts from the early 1940s. 